\title{
Plant responses to defoliation and relationships with pasture persistence
}

\author{
G.R. EDWARDS ${ }^{1}$ and D.F. CHAPMAN ${ }^{2}$ \\ ${ }^{1}$ Agriculture and Life Sciences Faculty, P.O. Box 84, Lincoln University 7647, Christchurch, 8240 \\ ${ }^{2}$ DairyNZ, P.O. Box 160, Lincoln University 7647, Christchurch, 8240 \\ grant.edwards@lincoln.ac.nz
}

\begin{abstract}
The effects of defoliation on plant morphology and the structure of perennial ryegrass and white clover populations are reviewed with reference to the persistence of yield in sown pastures. Maintenance of high densities of perennial ryegrass tillers and white clover stolons is fundamental to persistence. Tiller and stolon population densities are subject to within- and between-year variation, and are strongly influenced by defoliation management through processes such as competition for light, and size-density trade-offs mediated by self-thinning processes. Spring is a time when high tiller/stolon appearance and death rates occur simultaneously. Spring is also the time when clover populations undergo rapid structural change as large clover plants fragment to release small, unbranched plants with limited ability to compete for light with grasses. The central role of reproductive stem development in perennial ryegrass for summer survival of tillers and autumn re-establishment of tiller populations also highlights the importance of defoliation management during the spring for population persistence. Examples of the application of tactical defoliation management in spring, and at other times of the year, to manipulate stolon and tiller densities are presented. In some instances, such tactics may improve animal production potential, as well as the persistence of new cultivars. It is notable that the New Zealand literature on this topic is mostly more than 15 years old. Recent changes in farming systems and plant genotypes (e.g. tetraploidy in perennial ryegrass, late flowering perennial ryegrass) may require a reanalysis of established principles and practices related to defoliation $\mathrm{x}$ plant interactions in grazed pastures to ensure best possible pasture yield persistence and profitability of grazing systems.
\end{abstract}

Keywords: grazing management, perennial ryegrass, persistence, population dynamics, white clover

\section{Introduction}

The persistence of perennial ryegrass (Lolium perenne) and white clover (Trifolium repens) in grazed pastures is strongly dependent on the establishment and maintenance of populations of the basic plant growth units, tillers and stolons (Langer 1973; Valentine \& Matthew 1999). Defoliation is a key factor determining the survival, size and population density of the basic growth units. Defoliation disrupts plant energy supply, and triggers responses such as the re-distribution of carbon assimilate to leaf meristematic zones and mobilisation of carbohydrate reserves (Richards 1993). Persistence of pastures is strongly linked to how to how the growth units respond to the frequency, severity and timing of defoliation (Harris 1973).

The aim of this paper is to examine the effect of defoliation management on persistence of grazed perennial ryegrass-white clover pastures, drawing examples from both sheep and cattle grazing. The paper concentrates on persistence of yield derived from survival of the plants that were established from the seed that was sown, rather than persistence of specific traits held by the sown cultivars (Parsons et al. 2010; 2011). The paper is in two parts. First, the dynamics of the growth units of perennial ryegrass and white clover are examined under grazing, with the aim of identifying times of the year when populations are vulnerable to defoliation. Second, examples are given of how defoliation management may be used to improve persistence by increasing the survival, size and population of tillers and stolons.

\section{Pasture growth units}

When we consider the component of persistence that is related to plant and population survival, it is apparent that, for a pasture to 'persist', each plant, growing point or tiller must leave behind just one offspring. The population density of sown plants will remain stable if this condition is met. Perennial ryegrass and white clover are both clonal species, reproducing asexually via the production of daughter tillers or stolons which at some stage may become physically separated from the 'parent' tiller or stolon thereby resulting in the recruitment of a 'new' plant into the community (Chapman 1983). Recruitment of new plants from seed is often low in established pastures (Chapman 1987; L'Huillier \& Aislabie 1988; Edwards et al. 2005) due to strong asymmetric competition from adult plants and grazing management targeted at reducing 
Figure 1 Changes in ryegrass tiller density in pastures under rotational grazing, continuous grazing, or a combination of continuous and rotational grazing in spring and rotational grazing thereafter, at Palmerston North. Grazing method treatments were stocked with 22.5 ewe equivalents per hectare (from Brock \& Hay 1993).

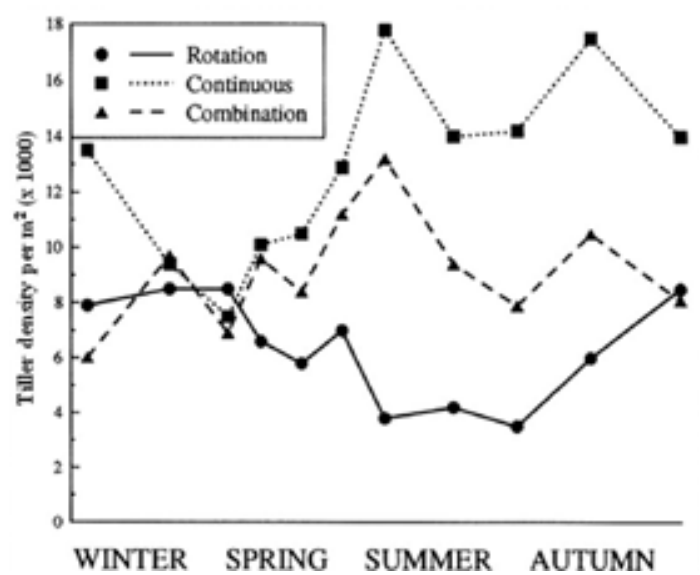

the production of seedheads and so opportunity for natural reseeding (Edwards et al. 2005). Where seed production is greater (e.g. delayed spring grazing) or where gaps appear in the dense perennial canopy (e.g., due to drought and insect pest attack) recruitment from seed may be of greater importance in the persistence of yield and may be required to sustain tiller and stolon populations (L'Huiller \& Aislabie 1988; Waller et al. 1999; Edwards et al. 2001). Indeed, L'Huiller \& Aislabie (1988) suggested that for perennial ryegrasswhite clover dairy pastures in the Waikato lax grazing to a residual of $2500 \mathrm{~kg} \mathrm{DM} / \mathrm{ha}$ and partial reseeding in summer on around $10-15 \%$ of the farm each year could be used to encourage seedling establishment and improve longer-term pasture persistence.

\section{White clover}

After germination, the growth of white clover is characterised by two distinct morphological growth phases, a seminal taprooted phase and a clonal growth phase (Brock et al. 2000). Death of the primary seminal taproot and primary stolon from 12 months after sowing (Brock et al. 2000) initiates a process of fragmentation of the taprooted plant into a variable number of independent clonal fragments (plants) which form the initial population of the clonal growth phase. White clover then spreads vegetatively by means of lateral extension of a system of branching stolons. Generally, growth of the stolon apex is balanced by periodic death of older basal stolon made redundant by new growth (Kershaw 1959; Hollowell 1966). This releases the branches to form new plants of varying size and branching complexity. The frequency distribution of plant size is log normal, indicating the population often compromises a few large plants and many small plants, irrespective of management or season (Hay et al. 1990).

The growth and death rates of stolon material are usually in balance, except for mid spring. Here, the accelerated death of old stolon results in rapid plant fragmentation and a shift in population structure toward a higher proportion of small, unbranched plants (Brock et al. 1988). However, plant numbers do not increase dramatically during this time period (Hay et al. 1989a), suggesting that many of the small plants must die. Furthermore, at this time axillary bud development in white clover and carbohydrate levels are at their lowest (Hay et al. 1989b). Since the population of growing points from which herbage is produced is not affected, the impacts of fragmentation on yield may not be readily apparent. However, it is notable that the stolon mass supporting the growing points is reduced, which may place the whole population at risk (Brock \& Hay 1993).

\section{Perennial ryegrass}

New tillers are produced continually in perennial ryegrass, but at different rates depending on season (Chapman et al. 1983; Korte 1986; L'Huillier 1987). However, due to considerable inter-year variation, and the effects of grazing management and pasture mass, a

Table 1 Effects of grazing method and cultivar phenotype on white clover leaf size, stolon density and contribution to total pasture dry matter. Data are means for two years. $\mathrm{RG}=$ rotational grazing; $\mathrm{SS}=$ set stocking. Both grazing method treatments were stocked with 22.5 ewes and lambs per hectare. From Brock (1988).

\begin{tabular}{|c|c|c|c|c|c|c|c|}
\hline \multirow[t]{2}{*}{ Cultivar } & \multirow[t]{2}{*}{ Leaf phenotype } & \multicolumn{2}{|c|}{ Area per leaf $\left(\mathrm{cm}^{2}\right)$} & \multicolumn{2}{|c|}{$\begin{array}{l}\text { Stolon growing points } \\
\left(\mathrm{no} . / \mathrm{m}^{2}\right)\end{array}$} & \multicolumn{2}{|c|}{$\begin{array}{l}\text { Clover content } \\
\text { (\% pasture DM) }\end{array}$} \\
\hline & & RG & SS & $\mathrm{RG}$ & SS & $\mathrm{RG}$ & SS \\
\hline Tahora & Small-leaved & 2.09 & 1.30 & 3750 & 10480 & 13.3 & 20.8 \\
\hline Huia & Medium-leaved & 2.75 & 1.15 & 2750 & 4720 & 11.0 & 13.1 \\
\hline Pitau & Medium/large-leaved & 4.08 & 1.30 & 2230 & 2880 & 15.1 & 7.0 \\
\hline \multirow[t]{2}{*}{ Kopu } & Large-leaved & 5.58 & 1.66 & 1530 & 2540 & 19.5 & 7.3 \\
\hline & $\mathrm{LSD}_{0.05}$ & 0.35 & & 110 & & 2.8 & \\
\hline
\end{tabular}


Figure 2 Fitted trend lines representing perennial ryegrass tiller density in response to spring dairy cow defoliation management. Treatment definitions are: HAY, hay; SIL, silage; LFLI, low frequency, low intensity; LFHI, low frequency, high intensity; MFMI, medium frequency, medium intensity; HFLI, high frequency, low intensity; HFHI, high frequency, high intensity; and RG, rapid grazing (from McKenzie 2006b).

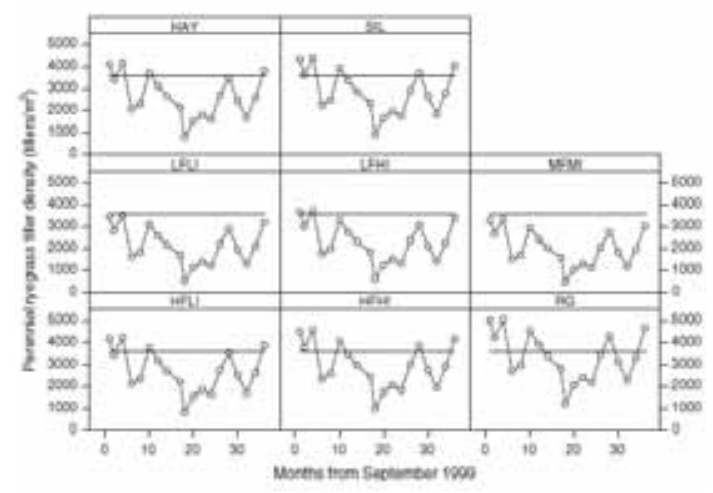

consistent seasonal pattern of tiller density is not always evident (Chapman et al. 1983; Korte 1986; Bahmani et al. 2001). In general, tiller appearance rates increase before flowering in mid spring (Chapman et al. 1983; Korte 1986; Matthew et al. 2000). However, tiller death rates also tend to peak in spring, probably reflecting the effects of higher pasture mass, including high leaf area index and shading of the lower layers of the canopy on mortality of small, newly-formed tillers (Ong \& Marshall 1979). Thus, as for white clover, spring, is a important period for the maintenance of tiller density and persistence of the population, although ryegrass tillers regenerating in summer from tiller buds on reproductive stems may compensate for high tiller death if climatic conditions allow (Korte 1986; Waller et al. 1999; Matthew et al. 2000).

\section{Defoliation management}

\section{Grazing method: continuous versus rotational}

Knowing when the major periods of new tiller and stolon recruitment occur can help to identify changes to pasture management that may be required for the successful establishment of new, independent plants. From the analyses of plant growth processes above, it is evident that both white clover and perennial ryegrass may have a period of vulnerability during the re-establishment of the basic plant population over the mid spring to early summer period. In most New Zealand pastoral regions, perennial ryegrasswhite clover pastures are not normally subjected to severe environmental stress during this period, and defoliation management is directed toward controlling competitive stress and pasture quality. In this period,
Figure 3 The differential effect of early summer drought on white clover performance over 4 years under rotational versus continuous grazing at Palmerston North expressed as changes in stolon biomass and growing points (from Brock \& Hay 1993).

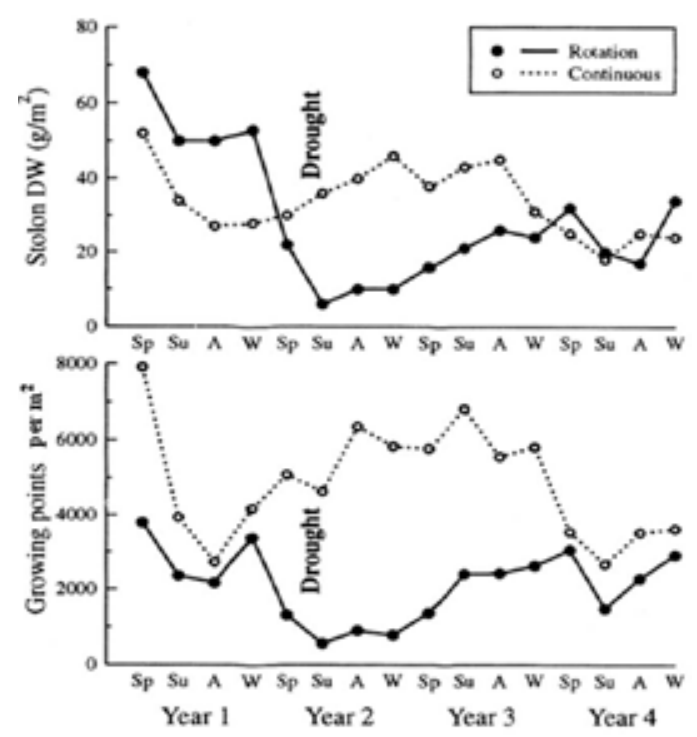

supplying sufficient feed from pasture to meet animal requirements is often not a problem; rather, there may be a problem of controlling an excess of pasture growth (Clark 1994). Practices such as silage or hay conservation may be useful processes in maintaining pasture quality on parts of farm; however, enhanced competition between tillers may negatively affect tiller density going into summer through self-thinning principles (see Matthew et al. 1995; 2000).

In sheep grazed pastures, continuous grazing over the spring period at low herbage masses not only helps to control seedhead development but promotes high tiller density (Fig. 1, Brock \& Hay 1993). This will reflect a combination of processes including reduced defoliation stress aiding the survival of tillers and growing points as well as the general tiller size- tiller density compensatory response that occurs in response to reduced grazing height in grass swards (Brock \& Hay 1993; Matthew et al. 2000). A change to rotational grazing management in summer to capitalise on these gains in tiller density, may allow greater expression of the growth potential of improved pasture species at other times of the year when seasonal shortages of production are of greater importance (Brock \& Hay 1993). It also improves the ability of ryegrass plants to take advantage of the niches created in the sward, for example, those created by tiller damage, tiller death due to temperature and moisture stress and selection by grazers (Thom et al. 1986; Chapman et al. 2011, this volume). In addition, the combined continuous- 
rotational defoliation management may be particularly effective in reducing weed invasion through the associated effects of dense pasture reducing weed seedling establishment in spring and intense rotational defoliation reducing weed seedling survival (Edwards et al. 2005; Tozer et al. 2011, this volume).

There is also some evidence of a similar response for white clover. In Southland, Hay \& Baxter (1989) found that heavy continuous sheep grazing during spring to maintain $500 \mathrm{~kg} \mathrm{DM} / \mathrm{ha}$ above $1 \mathrm{~cm}$ compared with rotational grazing to $2 \mathrm{~cm}$ residual pasture height at intervals 2, 3 and 4 weeks increased clover stolon density, presumably by reducing herbage mass and therefore competition for light between grass and clover at a time when the clover population structure is shifting toward smaller plants. This resulted in clover dominant pastures for lamb finishing in summer. There is, however, an important interaction here between grazing method and white clover phenotype, which is well illustrated by the results of Brock (1988). Smaller-leaved, prostrate plant types are better suited to the more-frequent defoliation (at the individual plant level) typically experienced under continuous grazing compared to rotational grazing than large-leaved, erect types (Table 1). This is because they are able to position more leaf below grazing height (Chapman 1986) and so more effectively avoid (sensu Briske 1986) the effects of frequent defoliation including loss of current photosynthate supply from residual leaf. By contrast, longer regrowth intervals typically experienced under rotational compared to continuous grazing allow largerleaved cultivars to express their growth potential (e.g. through leaf size, Table 1), resulting in higher clover content in the pasture compared to small-leaved types, though not necessarily higher stolon density (Table 1).

\section{Frequency, severity and timing under rotational grazing}

The importance of frequent and intense defoliation in spring to enhance tiller densities has also been highlighted under dairy cattle grazing. In a 3-year study in south-western Victoria ( $780 \mathrm{~mm}$ mean annual rainfall) (McKenzie et al. 2006a; b), the effect of different spring (September-November) defoliation strategies and common management throughout the rest of the year (grazed at the 3-leaf stage) on tiller densities and botanical composition was examined in ryegrass-white clover pastures grazed by dairy cows. While perennial ryegrass tiller densities declined over time in all treatments, rapid grazing to maintain pastures between 1500 and $1800 \mathrm{~kg} \mathrm{DM} / \mathrm{ha}$ and grazing at high frequency and high intensity (to $3 \mathrm{~cm}$ at the 2-leaf ryegrass leaf development stage) resulted in higher perennial ryegrass tiller densities than low (grazing at 3-leaf stage) and medium (grazing at 4-leaf stage) grazing frequency treatments, and forage conservation treatments (Fig. 2). The frequent and intense spring grazing also maintained high pasture DM yields and improved metabolisable energy, crude protein and neutral detergent fibre contents. In a study of perennial ryegrass-white clover dairy pastures in the Waikato (Thom \& Bryant 1993), a rapid 5-day rotation during spring (mid September to end November) followed by a 30-day rotation in summer and autumn produced similar milksolids yields to the more traditional 30-day rotation. However, the resulting pasture had a higher tiller density and clover content. Fast rotations in spring (c. 3500 tillers $/ \mathrm{m}^{2}$ ) had perennial ryegrass tiller densities that were about $15 \%$ greater over a 15 -month period compared with those from a 30-day rotation (c. 3000 tillers $/ \mathrm{m}^{2}$ ). Combined, these studies reinforce the importance of adopting frequent and intense grazing for perennial ryegrass dominant dairy pastures in the environments tested.

\section{Tactical spring defoliation}

A further defoliation approach to manipulating tiller survival is provided by Matthew et al. (1991). Vegetative tillers that become reproductive have a much higher chance of death compared to those that remain vegetative (Thom 1991). Furthermore, if defoliation of the reproductive parent tiller is left too late (e.g., late flower stage), competition for nutrients from the developing seedhead may have a negative effect on daughter tiller survival (Korte et al. 1984; L'Huillier 1987). From this, severe grazing has been advocated as a management tool to encourage growth of vegetative buds from basal buds (Korte et al. 1984). However, Matthew et al. (1991) showed that daughter tiller development is inhibited by severe or early defoliation and can be enhanced by allowing the reproductive parent tiller to develop to the early flower stage before being removed by defoliation (Matthew et al. 1993). The enhanced survival may reflect the better nutrition of daughter tillers through strongly growing parent tiller combined with re-absorption of nutrients from the developing defoliated tiller. Da Silva et al. (2004) examined this concept in a series of three trials in perennial ryegrass-white clover pastures in the Manawatu. Compared to conventional close grazing (grazing to residual of 30-50 mm every 20-21 days in spring and 28-30 days in summer, residuals c. 1600 to $2700 \mathrm{~kg} \mathrm{DM} / \mathrm{ha}$ ), late control (grazing or cutting to residual of $80-100 \mathrm{~mm}$ every $20-21$ days in spring, residuals $c$. $2000-2700 \mathrm{~kg} \mathrm{DM} / \mathrm{ha}$ ) followed by a switch to hard grazing $(30-50 \mathrm{~mm})$ at anthesis (28-30 days in summer, residuals $c .1600$ to $2700 \mathrm{~kg} \mathrm{DM} / \mathrm{ha}$ ) resulted in an average herbage production increase of $24 \%$ in 
October and November and 22\% in January to April. The increase in herbage production in spring was a consequence of greater perennial ryegrass reproductive development with late control and it contributed to lower sward and diet quality. Increased summer herbage accumulation was attributed to enhanced tillering activity post flowering. However, of note is that the window of opportunity for defoliation is obviously narrow. Indeed, this approach proved difficult to implement at the whole-system level (Bishop-Hurley et al. 1998) but remains one of only a few examples of the application of ecophysiological information to the solution of practical problems of production and persistence in grazed pastures.

\section{Defoliation to reduce environmental stress}

An important question is whether defoliation management can alleviate the effects of extreme or episodic events on pasture growth and persistence, such as drought or insect pest attack. In the New Zealand pasture context, late spring or early summer droughts may have marked impacts. In sheep-grazed pastures in Canterbury, spring droughts in successive years, reduced white clover content by $70 \%$ in each year, with little recovery in between (Vartha \& Hoglund 1983). Similarly, in the Manawatu, a severe drought in a 12-year sheep grazing experiment reduced the white clover population by $85-90 \%$ (Brock 1988). From this decline, it took clover populations 3 years to recover (Fig. 3). The notable point, however, from the Brock (1988) study was that losses of white clover stolon, and time taken to recover from drought, were much more pronounced under pastures that were rotationally grazed through the spring than those that were continuously grazed. The main explanation for these results was that the generation of dense pasture in spring reduced direct solar radiation to the soil surface and hence heat stress to plants once soil moisture had fallen below critical levels. Where pastures were continuously grazed (11 $000-15000$ tillers $/ \mathrm{m}^{2}$, bare ground $<3 \%$ ) soil surface temperatures were consistently lower $\left(40^{\circ} \mathrm{C}\right)$ than under rotational grazing (5000-6000 tillers $/ \mathrm{m}^{2}, 15-$ $20 \%$ bare ground and $48^{\circ} \mathrm{C}$ ) (Brock \& Hay 1993; see also Edwards et al. 2005). Further research (Brock \& Kim 1994), provided support for the beneficial effects of soil shading on white clover survival. Moreover, it was shown that a higher density of nodes was of greater significance for survival than the size of plants or root characteristics. It appears that the key role of defoliation management in this case is in the pre-drought period, with continuous grazing placing pastures in a better condition for drought tolerance.

Defoliation management to enhance tiller density prior to a drought may also result in faster recovery following relief of drought (Barker et al. 1985; Kemp \& Culvenor 1994). In keeping with the recommendation of Appadurai \& Holmes (1964) this set of studies used close defoliation prior to drought and avoided close grazing during drought. Once in the drought period, there is probably no specific defoliation management to improve pasture persistence (McKenzie et al. 2004), other than destocking and using conserved feeds in order to prevent selective and intense grazing. Together, these ryegrass and clover studies emphasize the key role of defoliation management in the pre-drought period in placing pastures in a better condition for responding to drought.

\section{Conclusions}

There is a solid body of information on the dynamics of perennial ryegrass tiller and white clover stolon morphology and populations in New Zealand pastures. This information reveals distinct periods of risk to population density associated with seasonal changes in conditions for plant growth and in plant structure. Spring appears to be the key season: while rates of recruitment of new tillers and stolons are generally high during this time, rates of death are also high, and clover plant fragmentation pushes population structure toward dominance of small, unbranched plants with limited ability to compete with fast-growing grasses. Outcomes of studies into the management of reproductive development in perennial ryegrass, as they affect tiller initiation and survival relative to pasture growth and quality, remain equivocal: further investigation of these interactions is warranted. It is notable that much of the literature consulted in compiling this review is more than 15 years old. In that time, there have been substantial changes in farming systems (e.g. a trend to higher stocking rates in dairy production systems), and the advent of new plant types (e.g. the release of more tetraploidy and late-flowering perennial ryegrasses). While the principles derived from this research are likely to be transferable, differences in vegetative and reproductive tillering patterns have been found among ryegrass ecotypes in response to irrigation and nitrogen (Bahmani et al. 2001; 2002). Thus, it is surely worth considering whether the resultant practices need further development to ensure that persistence of new pasture plant germplasm is not compromised.

\section{REFERENCES}

Appardurai, R.R.; Holmes, W. 1964. The influence of stage of regrowth, closeness of defoliation, and moisture on the growth and productivity of a ryegrass-white clover sward. I. Effect on herbage yields. Journal of Agricultural Science (Cambridge) 62: 327-332. 
Bahmani, I.; Thom, E.R.; Matthew, C.; Hooper, R.J; Lemaire, G. 2001. Tiller dynamics of perennial ryegrass cultivars derived from different New Zealand ecotypes: effects of cultivar, season, nitrogen fertiliser and irrigation. Australian Journal of Agricultural Research 54: 803-817.

Bahmani, I.; Thom, E.R.; Matthew, C.; Lemaire, G. 2002. Flowering propensity of two New Zealand perennial ryegrass cultivars originating from different ecotypes. New Zealand Journal of Agricultural Research 45: 129-137.

Barker, D.J.; Chu, A.C.P. 1985. Some effects of spring defoliation and drought on perennial ryegrass swards. Proceedings of the New Zealand Grassland Association 46: 57-63.

Bishop-Hurley, G.J.; Matthews, P.N.P.; Hodgson, J.; Dake, C.; Matthew, C. 1998. Dairy systems study of the effects of contrasting spring grazing managements on pasture and animal production. Proceedings of the New Zealand Grassland Association 59: 209-214.

Briske, D.D. 1986. Plant response to defoliation: morphological consideration and allocation priorities, pp. 425-427. In: Rangelands: A Resource Under Siege. Eds. Joss, P.J., Lynch, P.W., Williams, O.B. Cambridge University Press, U.K.

Brock, J.L. 1988. Evaluation of some New Zealand bred white clover cultivars under rotational grazing and set stocking with sheep. Proceedings of the New Zealand Grassland Association 49: 203-206.

Brock, J.L.; Hay, M.J.M.; Thomas, V.J.; Sedcole, J.R. 1988. Morphology of white clover (Trifolium repens L.) plants in pastures under intensive sheep grazing. Journal of Agricultural Science, Cambridge 111: 273-283.

Brock, J.L.; Hay, R.J.M. 1993. An ecological approach to forage management. pp. 837-842. In: Proceedings of the XVII International Grassland Congress.

Brock, J.L.; Kim, M.C. 1994. Influence of the stolon/ soil surface interface and plant morphology on the survival of white clover during severe drought stress. Proceedings of the New Zealand Grassland Association 56: 87-91.

Brock, J.L.; Albrecht, K.A.; Tilbrook, J.C.; Hay, M.J.M. 2000. Morphology of white clover during development from seed to clonal populations in grazed pastures. Journal of Agricultural Science, Cambridge 135: 103-111.

Chapman, D.F. 1983. Growth and demography of Trifolium repens stolons in grazed hill pastures. Journal of Applied Ecology 20: 597-608.

Chapman, D.F. 1986. Development, removal and death of white clover leaves under 3 grazing managements in hill country. New Zealand Journal of Agricultural Research 29: 39-47.
Chapman, D.F. 1987. Natural re-seeding and Trifolium repens demography in grazed hill pastures. II. Seedling appearance and survival. Journal of Applied Ecology 24: 1037-1043.

Chapman, D.F.; Clark, D.A.; Land, C.A.; Dymock, N. 1983. Leaf and tiller growth of Lolium perenne and Agrostis spp. and leaf appearance rates or Trifolium repens in set stocked and rotationally grazed hill pastures. New Zealand Journal of Agricultural Research 26: 159-168.

Chapman, D.F.; Edwards, G.R; Nie, Z.N. 2011. Plant responses to climate and relationships with pasture persistence. Pasture Persistence. Grassland Research and Practice Series 15: 99-107.

Clark, D.A. 1994. Grazing for pasture management in New Zealand. pp. 53-61. In: Pasture Management Technology for the $21^{\text {st }}$ Century. Eds. Kemp, D.R., Michalk, D.L. CSIRO, East Melbourne.

Da Silva, S.C.; Hodgson, J.; Matthew, C.; Matthews, P.N.P.; Holmes, C.W. 2004. Herbage production and animal performance on perennial rygrass/white clover pastures under alternative spring grazing managements. Journal of Agricultural Science, Cambridge 142: 97-108.

Edwards, G.R.; Newton, P.C.D.; Clark, H. 2001 Effects of elevated $\mathrm{CO}_{2}$ on seed production and seedling recruitment in a sheep grazed pasture. Oecologia 127: 383-394.

Edwards, G.R.; Hay, M.J.M; Brock, J.L. 2005. Seedling recruitment dynamics of forage and weed species under continuous and rotational sheep grazing in a temperate New Zealand pasture. Grass and Forage Science 60: 186-199.

Harris, W. 1973. Defoliation as a determinant of the growth, persistence and composition of pastures. pp. 67-85. In: Plant relations in pastures. Ed. Wilson. J.R. CSIRO, East Melbourne.

Hay, R.J.M.; Baxter, G.S. 1989. Manipulating the plastic response of white clover through grazing in a cool, temperate climate in New Zealand. pp. 1053-1054. In: Proceedings of the XVI International Grassland Congress.

Hay, M.J.M.; Brock, J.L.; Thomas, V.J. 1989a. Density of Trifolium repens plants in mixed swards under intensive sheep grazing by sheep. Journal of Agricultural Science, Cambridge 113: 81-86.

Hay, M.J.M.; Chu, A.C.P.; Knighton, M.V.; Wewala, S. 1989b. Variation with season and node position in carbohydrate content of white clover stolons. pp.1059-1060. In: Proceedings of the XVI International Grassland Congress.

Hay, M.J.M.; Thomas, V.J.; Brock, J.L. 1990. Frequency distribution of shoot dry weight of plants in populations of Trifolium repens persisting 
by clonal growth in grazed pastures. Journal of Agricultural Science, Cambridge 113: 81-86.

Hollowell, E.A. 1966. White clover Trifolium repens L., annual or perennial? pp. 184-187. In: Proceedings of the X International Grassland Congress.

Kershaw, K.A. 1959. An investigation of the structure of a grassland community II. The pattern of Dactylis glomerata, Lolium perenne and Trifolium repens. Journal of Ecology 47: 31-43.

Kemp, D.R.; Culvenor, R.A. 1994. Improving the grazing and drought tolerance of temperate perennial grasses. New Zealand Journal of Agricultural Research 37: 365-378.

Korte, C.J.; Watkin, B.R.; Harris, W. 1984. Effect of timing and intensity of spring grazings on reproductive development, tillering and herbage production of perennial ryegrass dominant pasture. New Zealand Journal of Agricultural Research 25: 309-319.

Korte, C.J. 1986. Tillering in 'Grasslands Nui' perennial ryegrass swards. 2. Seasonal pattern of tillering and age of flowering tillers with two mowing frequencies. New Zealand Journal of Agricultural Research 29: 629-638.

Langer, R.H.M. 1973. Growth of grasses and clovers. pp 41-64. In: Pastures and Pasture Plants. Ed. Langer R.H.M. A.H. \& A.W. Reed, Wellington, NZ.

L'Huillier, P.J. 1987. Tiller appearance and death of Lolium perenne in mixed swards grazed by dairy cattle at two stocking rates. New Zealand Journal of Agricultural Research 30: 15-22.

L'Huillier, P.J.; Aislabie, D.W. 1988. Natural reseeding in perennial ryegrass/white clover dairy pastures. Proceedings of the New Zealand Grassland Association 49: 111-115.

McKenzie, F.R.; Jacobs, J.L.; Kearny, G. 2004. Dairy pasture yield and growth responses to summer and spring grazing. Proceedings of the New Zealand Agronomy Society 34: 21-30.

McKenzie, F.R.; Jacobs, J.L.; Kearney, G. 2006a. Effects of spring grazing on dryland perennial ryegrass/white clover dairy pastures. 1. Pasture accumulation rates, dry matter consumed and nutritive characteristics. Australian Journal of Agricultural Research 57: 543-554.

McKenzie, F.R.; Jacobs, J.L.; Kearney, G. 2006b. Effects of spring grazing on dryland perennial ryegrass/white clover dairy pastures. 2. Botanical composition, tiller, and plant densities. Australian Journal of Agricultural Research 57: 555-563. http:// www.publish.csiro.au/nid/40/paper/ar05024.htm

Matthew, C.; Chu, A.C.P.; Hodgson, J.; Mackay, A.D. 1991. Early summer pasture control: what suits the plant? Proceedings of the New Zealand Grassland
Association 43: 125-132.

Matthew, C.; Black, C.K.; Butler, B.M. 1993. Tiller dynamics of perennation in three herbage grasses. pp.141-143. In: Proceedings of the XVII International Grassland Congress.

Matthew, C.; Lemaire, G.; Sackville Hamilton, N.R.; Hernandez Garay, A. 1995. A modified self-thinning equation to describe size/density relationships for defoliated swards. Annals of Botany 76: 579-587.

Matthew, C.; Asseuro, S.G.; Black, C.K.; Sackville Hamilton N.R. 2000. Tiller dynamics of grazed swards. pp. 127-150. In: Grassland ecophysiology and grazing ecology. Eds. Lemaire, G.; Hodgson, J.; de Moraes, A.; Nabinger, C.; de F. Carvalho, P.C. CAB International, Wallingford.

Matthew, C.; Hernández Garay, A.; Hodgson, J. 2000. "Late control" spring grazing management of perennial ryegrass swards: effect on sward structure and botanical composition. Proceedings of the Agronomy Society of New Zealand 30: 121-127.

Ong, C.K.; Marshall, C. 1979. The growth and survival of severely shaded tillers in Lolium perenne L. Annals of Botany 43: 147-155.

Parsons, A.J.; Edwards, G.R.; Newton, P.C.D.; Chapman, D.F.; Caradus, J.R.; Rasmussen, S.; Rowarth, J.S. 2010. Past lessons and future prospects: plant breeding for cool temperate pastures. pp. 272291. In: Proceedings of the $4^{\text {th }}$ Australasian Dairy Science Symposium. Eds. Edwards, G.R; Bryant, R.H.

Parsons, A.J.; Edwards, G.R.; Newton, P.C.D.; Chapman, D.F.; Caradus, J.R.; Rasmussen, S.; Rowarth, J.S. 2011. Past lessons and future prospects: plant breeding for yield and persistence in cool temperate pastures. Grass and Forage Science (in press).

Richards, J.H. 1993. Physiology of plants recovering from defoliation. pp. 85-93. In: Proceedings of the XVII International Grassland Congress.

Thom, E.R. 1991. Effect of spring grazing frequency on the reproductive growth and development of a perennial ryegrass tiller population. New Zealand Journal of Agricultural Research 24: 383-389.

Thom E.R.; Bryant, A.M. 1993. Effects of grazing management on the grass tiller density characteristics of a ryegrass/white clover dairy pasture. pp. 877-878. In: Proceedings of the XVII International Grassland Congress.

Thom, E.R.; Sheath, G.W.; Bryant, A.M; Cox, N.R. 1986. Renovation of pastures containing paspalum. 3. Effects of defoliation management and irrigation on ryegrass growth and persistence. New Zealand Journal of Agricultural Research 29: 599-611.

Tozer, K.; Bourdot, G.W.; Edwards, G.R. 2011. What factors lead to poor pasture persistence and weed 
ingress? Pasture Persistence. Grassland Research and Practice Series 15: 129-137.

Vartha, E.W.; Hoglund, J.H. 1983. What is the makeup of a dryland pasture? Proceedings of the New Zealand Grassland Association 44: 204-210.

Valentine, I.; Matthew, C. 1999. Plant growth, development and yield. pp. 11-27. In: New Zealand Pasture and Crop Science. Eds. White, J.G.H., Hodgson, J.
Waller, R.A.; Sale, P.W.G.; Saul, G.R.; Quigley, P.E.; Kearney, G.A. 1999. Tactical versus continuous stocking for persistence of perennial ryegrass (Lolium perenne L.) in pastures grazed by sheep in southwestern Victoria. Australian Journal of Experimental Agriculture 39: 265-274. 